\title{
Study Pemerintahan dan Tradisi Desa Wisata Pentingsari
}

Fuji Fani ${ }^{1{ }^{*}}$, Iis Sugiharti ${ }^{2}$, Suci Pertiwi ${ }^{3}$, Rio Junianto ${ }^{4}$

12)334)Program Studi PGSD Universitas Swadaya Gunung Jati; Jalan Pemuda No. 32

fujifani05@gmail.com, iissugiharti38669@gmail.com, Sucipertiwi1105@gmail.com, riojunianto9@gmail.com

Abstrak. Desa wisata penting sari merupakan tempat yang layak untuk wisata keilmuan, selain itu juga terdapat untuk bermanja-manja dengan keluarga, kerabat atau pasangan. dengan wisata alamnya dari dataran-dataran tinggi. Namun kali ini kita dapatkan hasil Dari beberapa pengamatan serta observasi langsung didesa wisata penting sari bahwa sebagai desa wisata yang sudah disahkan sejak tahun 2007. dalam pengembangan sebagai desa wisata, desa penting sari memiliki juga keragaman tradisi dan budaya, didimanfaatkan pengelola desa wisata penting sari untuk menjadi nilai tambahan sebagai pengetahuan ataupun wawasan bagi para wisatawan sehinga dapat dimanfaatkan dalam pembelajaran PKN SD, mata pelajaran PKN di SD terdapat kehidupan sosial tentang cara bermasyarakat seperti diadakannya kelompok-kelompok sosial sebagai bentuk untuk mengamalkan dasar-dasar pancasila sebagai tujuan bangsa indonesia dalam membentuk warga negara yang baik, jujur dan bertanggung jawab.

Kata Kunci. Kearifan Lokal, Pemerintahan, Desa Wisata Pentingsari

Abstract. Important sari tourism village is a decent place for scientific tourism, besides that it is also available to be spoiled with family, relatives or partners. With its natural tourism from the highlands. But this time we get the results. From several observations in important tourist villages, sari as a tourist village that has been ratified since 2007. In the development as tourist village, the important village of Sari has also a diversity of traditions and cultures, utilized by important tourism village management sari be an additional value as knowlege or insight for tourists so that it can be used in learning PKN SD, PKN subjects in elementary school have social life about how to socialize such as holding social groups as a form to practice the principles of Pancasila as the Indonesia nation's goal in forming citizes a good, honest and responsible country.

Caruban : Jurnal Ilmiah Pendidikan Dasar 1(2), 119-130, Juli 2018

p-ISSN 2615-1391, e-ISSN 2620-3219 @Prodi PGSD Universitas Swadaya Gunung Jati 
Keywords. Local Wisdom, Government, Pentingsari Tourism Village.

\section{Pendahuluan}

Dusun Pentingsari memulai aktifitas sebagai sebuah desa wisata sejak 15 Mei 2008. Desa wisata Pentingsari dapat disebut sebagai sebuah destinasi wisata karena didalamnya terdapat komponen akomodasi dan aktifitas yang terkait dengan kegiatan wisata. Dusun Pentingsari resmi menjadi desa wisata pada tanggal 15 April 2008 berdasarkan surat Dinas Pariwisata Kabupaten Sleman nomor 556/336. Saat ini Desa wisata Pentingsari atau lebih dikenal sebagai Dewi Peri menjadi Desa wisata terbaik di Provinsi Daerah Istimewa Yogyakarta, hingga kini Pentingsari masih aktif sebagai sebuah Desa wisata dan menerima pengunjung secara rutin. Pihak pengelola Desa wisata Pentingsari yang merupakan warga setempat telah mengemas sedemikian rupa potensi Desa mereka agar mempunyai nilai jual yang positif bagi wisatawan yang akan berkunjung. Maka dalam penyelenggaraan membangun desa wisata tersebut, untuk mewujudkannya perlu pengorganisasian yang mampu menggerakan masyarakat untuk dapat berpartisipasi menjadi bagian dalam pengelolaan Desa Wisata Pentingsari serta perlu bantuan-bantuan pemerintah desa dalam menunjang pergerakan untuk menjadikan sebagai desa wisata. Dengan demikian diharapkan pengelolaan untuk dapat mengoperasikan sebagai desa wisata, perlu organisasi yang terstruktur rapi dan jelas sehingga terlaksananya desa wisata tersebut.

Selanjutnya manfaat dalam aktifitas kepariwisataan kini semakin intens, dalam mengunjungi desa wisata yang sudah populer tersebut kini mulai menyadari bahwa mereka bisa berperan dalam kegiatan kepariwisataan untuk menarik para wisatawan. Dalam hal ini maka munculah kemudian desa-desa yang menyediakan aktifitas wisata dengan menunujakan keragaman tradisi atau budayanya yaitu sebagai desa wisata. Desa wisata adalah salah satu bentuk daya tarik terbesar sebagai suatu bentuk integrasi yang menyatukan berbagai kebudayaan yang mesti dilestarikan untuk mengundang partisipasi aktif masyarakat (Kementrian Kebudayaan dan Pariwisata, 2011). Pada 
dasarnya keberadaan Desa wisata adalah salah satu kegiatan pariwisata yang berbasis masyarakat setempat atau Community Base Tourism (CBT), untuk dapat berusaha melestarikan nilai-nilai tradisi di Dusun Penting sari tidak punah. Desa wisata Pentingsari memiliki beberapa sarana fisik essential evidence antara lain home stay, fasilitas petualangan outbond, rumah joglo, pendopo, dan aksesibilitas berupa jalan.

Dalam menjadikan penting sari sebagai desa wisata tersebut. perlu adanya kerja sama dari setiap komponen-komponen penyelenggara baik itu kepengurusan inti maupun pembantu untuk mempermudah melaksanakan tugasnya masing-masing. Sehingga agar terciptanya tujuan bersama serta rancangan-rancangan kegiatan masyarakatnya, yang dapat dijadikan kegiatan sosial sebagai daya tarik tersendiri. Dengan demikian sebagai perwujudan desa wisata pentingsari yang dapat menunjukkan berbagai aktivitas-aktivitas masyarakat dalam hidup rukun bertetangga maka tersangkut paut dengan Pembelajaran PKN yang dapat diterapkan sebagai pembelajaran pada Sekolah Dasar. Mata Pelajaran Pendidikan Kewarganegaraan (PKN) merupakan mata pelajaran yang di dalamnya memuat rumpun hukum, politik dan moral. PKn merupakan salah satu mata pelajaran yang diberikan di jenjang pendidikan Sekolah Dasar (SD). Mata pelajaran PKn merupakan mata pelajaran yang memfokuskan pada pembentukan warga negara untuk mempersiapkan diri menjadi generasi penerus yang memiliki kecakapan, pengetahuan serta nilainilai yang berguna untuk berpartisipasi aktif dalam masyarakat (Samsuri, 2011). Dalam mengunjungi desa wisata banyak sekali hal yang harus dipelajari dalam pembelajaran PKN khususnya, untuk menjadikannya sebagai sumber pengetahuan baru.

\section{Metode Penelitian}

1. Teknik Pengumpulan Data

Dalam mengumpulkan informasi tentang studi pemerintah dan tradisi Desa Wisata Pentingsari sebagai pembelajaran PKN di SD dilakukan dengan beberapa teknik pengumpulan data secara langsung pada lokasinya di Desa Wisata Pentingsari yang di lakukan oleh kelompok kami diantaranya yaitu, 
Wawancara, Untuk mengumpulkan data, penyusun menggunakan wawancara kepada responden dengan menggunakan wawancara terstruktur yaitu berlangsung dengan mengikuti pedoman yang telah disediakan. Yang berisikan pertanyaan-pertanyaan teratur dan tersusun yang akan diajukan kepada responden.Observasi, Yaitu dengan mengadakan pengamatan dan pencatatan langsung pada obyek yang diteliti untuk memperoleh data yang diperlukan selama penulis melakukan penelitian. Dari data observasi langsung, dalam pelasksanaan observasinya menggunakan peralatan mekanik yaitu dengan membuat rekaman dan catatan observasi dengan tujuan agar data-data tersebut tidak hilang ataupun keliru.Studi Dokumen, Yaitu mengumpulkan data dan informasi yang bersangkutan dengan Studi Pemerintahan dan Tradisi Desa Wisata Pentingsari, yakni dengan mengumpulkan foto yang dapat dijadikan sebagai bahan pertimbangan data yang terkumpul serta penguat dalam penulisan laporannya. Adapun tujuan dibuatkan jurnal ini untuk mengetahui struktural Desa Wisata Pentingsari serta mengenal tardisi dan budaya sebagai pembelajaran PKn di SD.

\section{Hasil Penelitian dan Pembahasan}

\section{A. struktur organisasi desa wisata pentingsari}

Desa wisata pentingsari merupakan bagian didalamnya dari dusun pentingsari. Desa wisata pentingsari ini di jadikan sebagai contoh dari desadesa lain karena memiliki potensi-potensi yang dapat menghasilkan suatu sumber ilmu pengetahuan bagi para pengunjung. Maka dari itu pengelola desa wisata pentingsari menyusun secara terstruktur agar terciptanya suasana yang kondusif sehingga pengunjung merasa puas serta nyaman dalam mengunjungi dusun wisata pentingsari ini.Desa wisata pentingsari ini di ketuai oleh bapak Doto Yogantoro sebagai ketua I dan Totok Irbananto sebagai ketua II, beliau merupakan salah satu pelopor dalam mendirikan desa wisata pentingsari, selain itu juga pelopor pertama ataupun sesepuh dari desa wisata pentingsari yaitu bapak Sumardi yang sekarang menjabat sebagai penasihat dari desa wisata penting sari,beliau sekarang berumur 92 tahun. Sedangkan dalam 
melindungi desa wisata penting sari yaitu pemerintah dusun penting sari serta atasan-atasan lainnya seperti pemerintah desa umbul harjo.

Dalam membangun organisasi desa wisata penting sari, bapak Doto Yogantoro tidak sendirian melaksanakan pengelolaan dusun penting sari ini, diantaranya dibantu para anggota-anggota kepengurusan yang bertanggung jawab sesuai tugasnya masing-masing diantaranya yaitu :

1. sekretaris

sekretaris yang membantu bapak Doto Yogantoro dalam mendampingi tugas ketua serta mencatat segala sesuatu bentuk administrasi dari keperluan desa wisata penting sari yaitu dipercaya oleh Helga kurnia dan Ari sulistiawan.

2. Bendahara

Selanjutnya bagian yang menangani masalah keuangan atau biasa kita sebut bendahara dipegang oleh kristina dan wismiati.

3. Koordinator kegiatan

Selanjutnya bagian-bagian koordinator yang bertanggung jawab dalam pelaksanaan kegiatan-kegiatan yang terdapat di desa wisata penting sari agar berjalan dengan baik, adapun kegiatan-kegiatan yang dilakukan pada saat mengunjujngi desa wisata penting sari yaitu kegiatan study alam, study pariwisataan, belajar kesenian, ngetrack dan masih banyak kegiatankegitan yang dapat dilakukan didesa penting sari. koordinator kegiatan ini diketuai oleh budiyanto dan dibantu angotanya wawan sukanto dan hendi hidayat. Tugas dari koordinator kegiatan ini melaksanakan kegiatankegitan yang telah disusun bersama untuk dilaksanakan ketika ada wisatawan berkunjung ke desa wisata penting sari.

4. Koordinator pembangunan

Koordinator pembangunan yang diketuai oleh maryanto, anggotanya yaitu basuki hermanto dan sariman. Tugas dari koordinator pembangunan yaitu melaksanakan memenuhi fasilitas-fasilitas yang belum tersedia didesa penting sari dari anggaran para wisatawan yang akan mengunjungi desa wisata penting sari, agar dari pembangunan fasilitas-fasilitas tersebut wisatawan merasa nyaman dengan fasilitas yang ada. 
5. Koordinator homestay

Koordinator homestay yang dipimpin oleh ngadiyono dengan dibantu oleh sumarto menjalankan tugas yaitu mengatur penginapan bagi para wisatawan yang berlama-lama didesa wisata penting sari, ada lebih dari 100 rumah yang bersedia memberikan tumpangan bagi para wisatawan, disitu wisatawan sudah diberikan pelayanan seperti makan 3 kali sehari, tempat tidur yang sudah disediakan dengan nyaman.

6. Koordinator konsumsi

Koordinator konsumsi tugasnya menyediakan keperluan bagi para wisatawan, namun biasanya makanan yang diberikan kepada wisatawan dibuat dari para homestay masing-masing sehingga koordinator konsumsi maupun koordinator homestay saling membantu dan bekerja sama untuk menyediakan berbagai keperluan yang disediakan oleh pengurus untuk para wisatawan seperti obat-obatan, makanan dan lain sebagainya yang dibutuhkan oleh wisatawan. Koordinator darri konsumsi dipegang oleh sumirah, lusi wulandari dan lis titik.

7. Koordinator kesenian

Koordinator yang diketuai oleh toni sukoyo, dengan dibantu oleh beberapa anggotanya yaitu sudiyar dan heru sutanto, ini melaksanakan untuk bertanggung jawab dalam pelaksanaan kesenian yang ada didesa wisata penting sari untuk terus dijaga dan dilestarikan agar para wisatawan mendapatkan kesan dari kunjungannya didesa wisata penting sari tersebut. kesenian yang ditampilkan didesa wisata penting sari ini beragam seperti belajar gamelan yang merupakan alat musik tradisional khas jawa, selanjutnya membuat janur yang terbuat dari rumbut membentuk tokoh wayang, kesenian-kesenian tersebut adalah bagian dari beberapa kesenian yang ada didesa wisata penting sari.

8. Koordinator cinderamata/produk kreatif masyarakat

Yaitu melaksanakan tugas menampung berbagai kreatifitas-kreatifitas masyarakat sebagai nilai jual untuk dikenalkan kepada para wisatawan. Koordiantor ini diketuai oleh murdini dan anggotanya aswati.

9. Koordinator marketing/komunikasi medsos 
Koordinator marketing tugasnya melaksanakan promosi-promosi kepada masyarakat luar baik melalui ucapan ke uacpan maupun melalui berbagai alat komunikasi seperti media sosial, selain itu mengkoordinir para wisatawan jika ada yang akan mengunjungi desa wisata penting sari maka bagian koordinator marketing memberikan pelayanan yang nyaman untuk berkomunikasi untuk berkunjung. Koordinator marketing diketuai oleh bayu hindra dan beranggotakan yoga trianjan dan eka pratama.

10. Koordinator usaha kreatif/pengembangan sarana atau prasarana

Koordinator usaha melakukan penambahan sarana dan prasarana untuk nilai tambahan didesa wisata pentingsari sebagai hiburan maupun kegiatan tambahan yang membutuhkan tempat yang nyaman seperti didirikannya adanya perkemahan bagi para wisatawan ataupun pengunjung setempat jika mau berkemah, maka didesa wisata pentingsari menyediakan tempat tersebut ataupun sarana tempat berkumpul bagi para wisatawan karena jarak didesa wisata yang berjauhan pada saat di home stay, maka dibuatkanlah sarana tempat berkumpul. Koordinator usaha kreatif dipimpin oleh dwi wahyu dan beranggotakan nugroho dwi dan veronika.

11. Koordinator keamanan

Koordinator keamanan tugasnya yaitu mengamankan segala sesuatu yang ada disekitar desa wisata penting sari agar selalu tertib, sehingga para wisatawan merasa aman dan tentram. Sehingga suasana yang ada didesa wista selalu kondusif. Koordiantor keamana dipercayakan kepada supardi, ponidi, dwi agung dan arif.

12. Koordinator humas

yaitu bertanggung jawab atas laporan-laporan yang masuk atau pun keluar, laporan kepada bagian lembaga-lembaga lain amupun kepada pihak yang bersangkutan dengan desa wisata penting sari. Diketuai oleh sugiwanto dan beranggotakan $\mathrm{H}$. radjim dan eko riyono.

\section{B. Pembelajaran PKN SD yang dapat dijadikan sumber belajar mengenai Studi Pemerintahan dan Tradisi di Desa Pentingsari}


Didesa wisata penting sari dalam menjadikan sebagai desa wisata penting sari yang menonjolkan keberadaan alam yang masih asri ataupun pertaniannya, ada juga dalam pemberdayaan masyarakat, sebagai suatu usaha untuk menjalin silatuhrahmi antar warga dusun penting sari dengan melakukan kegiatan-kegiatan yang sudah disusun sedemikian rupa sebagai bentuk mengamalkan pancasila. adapun kegiatan-kegiatan sosialnya yaitu kelompok koperasi,kegiatan ini dilakukan oleh seluruh masyarakat dusun pentingsari yang bersedia mengikuti kegiatan koperasi dengan pelaksanaannya yaitu membantu masyarakat dalam melaksanakan simpan pinjam, adapun tujuannya yaitu meringankan ketika ada masyarakat yang sedang mengalami kesulitan. Kemudian kelompok ke 2 yaitu ada kelompok lansia,kelompok ini di ikuti oleh sekumpulan-sekumpulan. Selanjutnya ada kelompok desa wisata pentingsari,kelompok ini melaksanakan kegiatan-kegiatan yang berhubungan dengan desa wisata seperti contohnya yang mengarungi serta membimbing para wisatawan-wisatawan yang berkunjung di dusun penting sari,serta menunjukkan bahwa dusun pentingsari memiliki potensi-potensi yang unik untuk menambah ilmu pengetahuan serta wawasan. Kemudian ada kelompok PKK, kelompok ini melakukan kegiatan-kegiatan membantu masyarakat dalam melakukan kegiatan tentang perkumpulan ibu-ibu baik itu dalam bidang keagamaan,sosial,kesehatan atau yang lainnya, selanjutnya ada kelompok pemuda-pemudi atau karang taruna, kelompok ini melaksanakan kegiatan yang bersangkutan dengan kepemudaan seperti contohnya kegiatan olahraga,keagamaan,serta sosial dalam membantu memakmurkan kepemudaan di dusun pentingsari.

Selanjutnya didesa wisata penting sari kehidupan masyarakatnya juga sangat kompak dalam penyelenggaraan dusunnya tersebut menjadikan sebagai desa wisata sehingga desa wisata penting sari banyak ditiru sebagai contoh dalam melakukan pemberdayaan masyarakatnya, hal ini kehidupan masyarakatnya sangat mengamalkan dasr-dasar pancasila sebagai contoh dalam segala sesuatu kegiatan dilakukan secara bermusyawarah baik kelompok kecil maupun kelompok besar yang mengundang seluruh warga dusun penting sari. Selanjutnya adanya keberagaman dalam saling menghargai perbedaan, 
baik perbedaan agama, ras ataupun suku. Didesa wisata penting sari sangat terbuka dan antusias dalam menerima tamu luar jawa maupun dalam jawa.

Tabel 1.struktur organisasi Desa Wisata Pentingsari

STRUKTUR ORGANISASI DESA WISATA PENTINGSARI PERIODE 2018-2020

\section{No}

Jabatan

1. Pelindung

2 Penasihat

3. Ketua I

4. Ketua II

5. Sekretaris I

6. Sekretaris II

7. Bendahara I

8. Bendahara II

9. Koordinator kegiatan
Nama

Rejo Mulyono

Sumardi

AG Waringi

Doto Yogantoro

Totok

Irbananto

Helga Kurnia P

Ari Sulistiawan

Kristina

Wismiati

Dian Anggraeni

Budiyanto

Wawan

Sukanto

Hendi Hidayat

\section{Tupoksi}

Melindungi setiap anggota organisasi

Membina serta membimbing para anggota dari organisasi

Menyelenggarakan, memimpin serta bertanggung jawab dengan segala sesuatu didalam organisasi Melakukan tugas mencatat (notulen) yang berhubungan dengan organisasi tersebut Tugasnya mengadministrasikan segala tentang keuangan dalam organisasi didesa penting sari Bertanggung jawab dengan segala kegiatan-kegiatan yang akan dilaksanakan kedepan didesa pentingsari 
10.

Koordinator

pembangunan

11. Koordinator homestay

12. Koordinator kesenian Sudiyar

Heru Sutanto

Sumirah

13. Koordinator konsumsi

Koordinator

14. cinderamata/produk kreatifitas masyarakat

Aswati

Dwi Wahyu S

Koordinator usaha

15. kreatif/pengembangan sarana atau prasarana

Koordinator

16. marketing/komunikasi medsos

Hermanto

Sariman

Ngadiyono

Sumarto

Lusi Wulandari

Lis Titik S

Murdini Eka Pratama
Maryanto

Basuki

Dwi Wahyus

Memfasilitasi segala kebutuhan (akomodasi) yang diperlukan dalam hal pembangunan.

Bertanggung jawab melaksanakan ketersediaan homestay bagi para pengunjung Bertanggung jawab dalam melaksanakan kegiatan kesenian didesa pentingsari

Bertanggung jawab dalam memfasilitasi sandang pangan bagi para pengunjung Bertanggung jawab dalam memfasilitasi kerajinan masyarakat.

Bertanggung jawab dalam melaksankaan pengembangan Nugroho Dwi sarana dan prasarana didesa $\mathrm{H}$ pentingsari agar wisatawan tertarik.

Yoga Trianjar Mensosialisasikan budaya dari desa penting sari melalui medsoso agar wisatawan tertarik 
Supardi

Poniti

17. Koordinator keamanan
Dwi Agung N

Arif S

Sugiwanto

18. Koordinator humas
H. Radjim

Eko Riyono
Bertanggung jawab atas

ketertiban,keamanan

serta

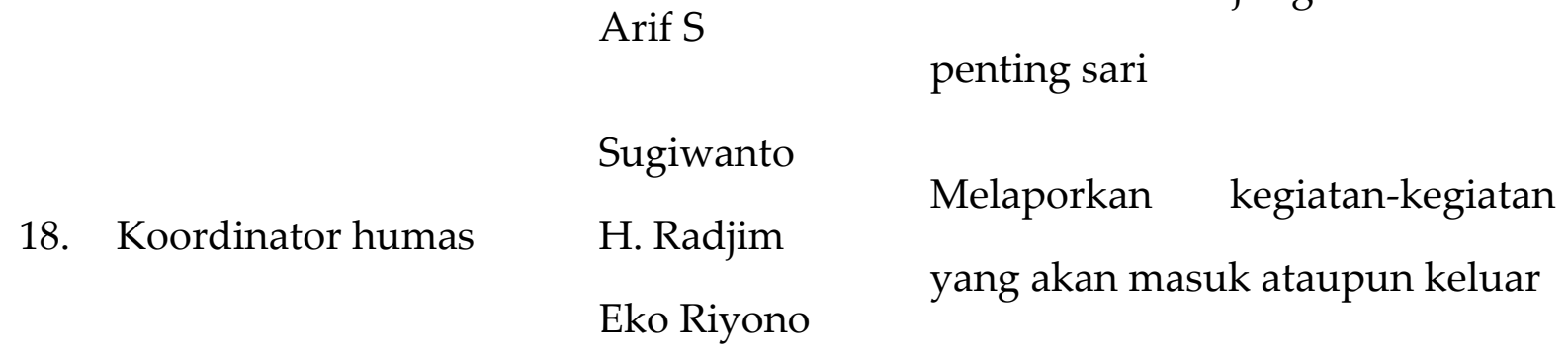

Dalam pembangunan Desa Wisata Pentingsari tersusun dibawah kelembagaan khusus yang mengatur dan mengelola Desa Wisata tersebut yang memiliki nama "Dewi Peri". Didalam susunan kepengurusan tersebut terdiri dari pelindung, penasihat, ketua, sekretaris, bendahara, dan seksi-seksi pemandu wisata, pemasaran, homestay, sie. konsumsi dll yang saling berkoordinasi untuk mencapai visi-misi serta tujuan demi kesejahteraan dan kemajuan Desa Wisata Pentingsari agar menjadi lebih baik.

\section{Simpulan}

Desa wisata pentingsari dijadikan sebagai desa wisata pada tahun 2008 oleh dinas kepariwisataan Yogyakarta, karena memiliki daya tarik sebagai desa yang mampumengembangkan potensi yang ada didesa pentingsari, sehingga desa tersebut diupayakan untuk terus menjaga kelestraiannya dibidang lingkungan alam, adat atau seninya yang menjadikan desa wisata pentingsari sebagai desa wisata. Oleh karena itu, untuk pemberdayaan serata pelestarian desa wisata dibentuk sebuah kepengurusan dalam menaungi segala bidang yang mampu untuk diterapkan didesa wisata penting sari, sehingga dengan pengelolaan yang baik menimbulkan kepercayaan yang baik pula oleh masyarakat. 
Pada pelaksanaan penelitian, diharapkan dalam menggunakan metode penelitian, dibuatkan instrumen secara rinci serta dibedakan antara instrumen observasi dan wawancara, agar data yang didapatkan jelas keterbuktiannya.

\section{Daftar Pustaka}

Adhie sathya. (2018). Jatilan tarian tradional jawa di https://www.pegipegi.com. (diakses 22 mei).

Fimela. (2018). Ritual tujuh bulanan adat jawa dihttps://www.fimela.com (diakses 20 maret)

Kompasiana, (2010). Kenduri dihttps://www.kompasiana.com. Diakses 10 juli.

Sugeng S. (2018). peran dan fungsi badan permusyawaratan desa (BPD) di eprints.umpo.ac.id. (diakses januari) 